INTERMARUM: history, policy, culture. - Issue 7.

UDC 94(477):281.93:266.3«19»

DOI $10.33287 / 112007$

Sychevsky Anton,

$\mathrm{PhD}$ (History), Senior Lecturer at the

Department of History of Ukraine, Zhytomyr Ivan Franko State University

syczewski@gmail.com

ORCID: http://orcid.org/0000-0002-7836-3405

\title{
OLD BELIEVERS IN THE EKATERINOSLAV DIOCESE AND ACTIVITIES OF ORTHODOX MISSION AT THE BEGINNING OF THE $20^{\text {th }}$ CENTURY
}

\section{Abstract}

The purpose of this study is to present the religious life of the Old Believers in the Ekaterinoslav diocese of at the beginning of the 20th century and analyze the specific nature of the Orthodox mission activities in their midst. The research methodology is based on the principles of historicism, consistency, author's objectivity, as well as on general scientific (analysis, synthesis, concretization, generalization) and special historical (problem-chronological, historical-genetic, historical-typological) methods. The problem-chronological method has been employed to analyze the religious life of the Old Belief communities in the Ekaterinoslav diocese and reveal the religious policy of the official Orthodox Church towards the Old Believers in the specified period. The historical-genetic method has been applied to analyze the transformations of the Old Belief in the Ekaterinoslav diocese and examine the confessional policy of the Orthodox Church. The historical-typological method has been adopted to study the internal separation and conflicts in the Old Belief of the Ekaterinoslav diocese and consider the forms of religious policy implementation. The scientific novelty of the undertaken researchlies in the fact that for the first time the internal distribution of the Old Belief in the Ekaterinoslav diocese has been comprehensively studied, the course of the conflict between the okruzhniki and the neokruzhniki has been disclosed, the forms and methods of missionary activity of the official Orthodox Church have been presented. Conclusions. At the beginning of the 20th 
IНТЕРМАРУМ: історія, політика, культура. - Вип. 7.

century, 10000 Old Believers lived in the Ekaterinoslav diocese. The popovtsy represented the overwhelming majority; the neokruzhniki, the bespopovtsy, and the beglopopovtsy were made up groups. The relations with priests, whose actions provoked indignation among the parish, caused the internal conflicts in the communities. The case of the priest $S$. Tokarev gained special publicity. The conflict was acute in popovshchina, between the okruzhniki and the neokruzhniki, that gradually began to decline after the act of reconciliation in 1906. On the way to reconciliation, the community of the okruzhniki faced an alleged provocation against Archbishop Ioann. The «fight» against the Old Believers remained the priority in the activities of the Orthodox missionary. The diocesan missionaries were opposed both by the representatives of the clergy and the ordinary Old Believers, and the authorities, namely the Old Belief nachyotchiki K. Peretrukhin, V. Zelenkov, L. Pichugin, and others. Despite the high level of organization and activities of the missionary institute, the immediate success of the mission was limited.

Key words: Old Belief, missionary, okruzhniki, neokruzhniki, bespopovtsy, Common Faith (Edinoverie), «Encyclical Epistle».

Introduction. Since Ukraine's declaration of independence, with the processes of democratization of the state-church relations, tendencies towards the revival of spiritual life have become evident in the society. Recently in modern historiography, there has been a growing interest in the history of religious communities. The Old Belief, that has become the basis of the national identity for part of the Russians, is of special importance. The phenomenon of the Old Belief lies in the fact that its supporters, having preserved centuries-old religious and cultural traditions, created a separate ethno-confessional group with their values. For centuries, the dominant state-church apparatus has been waging an uncompromising struggle against the «raskolniki» («schismatics») to suppress this religious movement. The institution of missionary performed a special role in those processes. The territory of the Ekaterinoslav diocese arouses research interest since it was one of the nests of the Old Believers in the Russian Empire.

Some issues on the history of the Old Believers in the Ekaterinoslav diocese has been previously investigated by the Ukrainian 
INTERMARUM: history, policy, culture. - Issue 7.

researchers. The first study concerning the Old Believers of Olkhovatka village in Donbass was carried out by G. Klepalova and I. Lukovenko (Klepalova, Lukovenko, 2001). M. Ruban, S. Tatarinov and O. Miroshnichenko sketched the position of the Old Believers in Donbass in the 18th - at the beginning of the 20th century (Ruban, Tatarynov, 2017; Miroshnychenko, 2019). S. Nestertsova and E. Mayorova comprehensively analyzed the Old Belief in Donbass in the 19th - early 20th centuries on the materials of the Old Belief periodicals (Nestertsova, Mayorova, 2012). However, the integrated study of the Old Belief in the whole Ekaterinoslav diocese at the beginning of the 20th century has not been carried yet.

The author of this article has previously surveyed the position of the Old Believers under the influence of the Orthodox mission on the example of the Volyn diocese (Sychevsky, 2012; Sychevsky, 2013a; Sychevsky, 2013b). The processes of the internal mission in this region and the Ekaterinoslav diocese had common features, and to a certain extent were similar, given the quantity of the supporters of the Old Belief in these regions.

Unfortunately, the issues of the internal separation of the Old Believers in the Ekaterinoslav diocese, the conflict between the okruzhniki and the neokruzhniki, the relations between priests and their parish, the activities of the Orthodox mission among the Old Believers have not yet been researched.

The purpose of the study is to reveal the religious life of the Old Believers of the Ekaterinoslav diocese in the early 20th century and to analyze the specifics of the Orthodox mission in their midst.

Findings and discussion. At the beginning of the 20th century around 9000 Old Believers lived in the Ekaterinoslav Diocese (Dorodnitsyn, 1901a, p. 221-222). According to their religious beliefs, the local Old Believers were divided into the Austrian faction (recognizing the Belokrinitsky hierarchy) - the okruzhniki, the neokruzhniki, the bespopovtsy and the beglopopovtsy. The okruzhniki, who lived in the villages of Gorodishche, Olkhovatka, Orekhovo, the cities of Ekaterinoslav and Rostov occupied the first place in terms of number (Ayvazov, 1903a, p. 327-328). The neokruzhniki lived in the village of Kamenskoye, the city of Ekaterinoslav, Nikopol and partly in Gorodishche. The bespopovtsy settled in the villages Troitskoe, 
IНТЕРМАРУМ: історія, політика, культура. - Вип. 7.

Orekhovo, Olkhovatka, Kamenskoye, Rostov, and a small number lived in Gorodishche. The bespopovtsy mainly settled in Orekhovo. The beglopopovtsy lived in small numbers in Rostov (Rusanov, 1905, p. 332-333; Report, 1907b, p. 239).

In 1880, not far from Gorodishche, the Old Believers illegally built the Preobrazhensky Skete, with the peasant Isidor Blinov from Olkhovatka village (Hieromonk Ioann) as the priest and three hieromonks. Initially, the Preobrazhensky Skete consisted of one dugout, but thanks to the activities of Blinov gained a flourishing position. The church functioned in it, there were the chambers for the priest, dormitories and separate houses for monks, an extensive refectory, a water mill, barns, stables, a chapel above the cemetery (all covered with icons inside), built in 1900. The monastery possessed about 70 acres of land (Dorodnitsyn, 1901a, p. 222-223).

About 200-300 people from all over Russia would gather in the Skete in the Assumption feast for the dedication day of the Transfiguration of the Lord, led by the priests, they were 10. The archbishop of Moscow and all Russia Ioann (Kartushin) and the Old Believer missionary Clement Peretrukhin frequently visited the Skete. In 1901, on behalf of the Orthodox missionary, A. Dorodnitsyn described the Skete: «Serving as a den for lovers of easy life, persons of dubious morals, who neglected their wives and children, the Skete is known as a place of careless fun and drunkenness. In the summertime, many «prominent persons» of raskol (schism) gather here to get drunk and have fun» (Dorodnitsyn, 1901a, p. 223).

The spiritual leaders of the Old Belief consisted of: in Gorodishche - local peasants, the priests Karp Foteev, Matvey and Karp Grigoryevs and nonresidents (the neokruzhnik priest) Pyotr Potemkin, in Olkhovatka - Emelyan Bezchastnov, in Orekhovo - Sergey Tokarev. In Rostov - Philip Privalov, in Kamenskoye (the neokruzhnik archpriest) Ioannikiy Antonov, in Ekaterinoslav - the nonresident priest Fedot Akimochkin, in Nikopol and Troitskoe the Old Believers were governed by ustavshchik (Dorodnitsyn, 1901a, p. 222).

The okruzhniki obeyed the Moscow Old Belief Archbishop Ioann (Kartushin). The highest control over the neokruzhniki members belonged to Bishop Mikhail of Novozybkov (the Chernigov diocese). The beglopopovtsy were registered as runaway priests who came from 
INTERMARUM: history, policy, culture. - Issue 7.

the Don diocese (Ayvazov, 1903a, p. 328). There were four spiritual fathers or nastavniki at the head of the bespopovtsy communities - two in Troitskoe, one in Orekhovo, and one in Olkhovatka (Rusanov, 1905, p. 333).

In 1903, the Old Believers settled mainly in eight locations in the diocese: Slavyanoserbsky county - Gorodishche (4666 people), Olkhovatka (1594), Orekhovo (640), Pavlograd county - Troitskoe (120), Ekaterinoslavsky county - Nikopol and Kamenskoye (900), Ekaterinoslav and Rostov - 800 (Ayvazov, 1904, p. 245). In a small number, they also lived in other cities and trading villages, mostly those who had come from Chernigov province (Dorodnitsyn, 1901a, p. 221222). In 1905, the Old Believers dwelt in the village of Dvoriki (the khutor of Nikitin), Slavyanoserbsky county (Report, 1907a, p. 233).

In 1909, 4966 Old Believers (2441 men and 2516 women) lived in Gorodishche: the okruzhniki included 2290 men and 2373 women, and the neokruzhniki consisted of 151 men and 143 women. In Olkhovatka village the popovtsy included 2360 persons (1180 men and 1180 women), the bespopovtsy - 54 (26 men and 28 women). In Orekhovo, there were 583 representatives of the Austrian faction ( 300 men and 283 women), 168 bespopovtsy ( 85 men and 83 women). The newly come Old Believers (up to 100 people) lived in Vasilievka village, Slavyanoserbsky county. Nine people dwelt at the Kadievsky plant (State of schism, 1910 p. 21), and their number increased to 140 people the following year. 104 Old Believers were registered in the city of Aleksandrovsk. In total, more than 10000 Old Believers lived in the diocese in 1911 (Afanasyev, 1912, p. 461).

The internal discord in the communities arose on the basis of the reprehensive attitude of the believers towards their priest. For example, in 1904 in the Assumption Church in Gorodishche, there was a conflict between the believers and the priest K. Foteev. Reporting about the conflict to Archbishop Ioann, the believers wrote: «Presently we are wandering sheep, and we do not have a shepherd... Drunkenness, even gambling, and foul language have begun in the church. And all this in the presence of Father Karp. Is it possible to allow such abominations in the yard of the House of our God?». Among other things, K. Foteev was accused of violating the sixth sacrament - marriage, as he had allowed his daughter to divorce with the husband (Rusanov, 1905, p. 332-333). 
IНТЕРМАРУМ: історія, політика, культура. - Вип. 7.

From the first days of his ministry, Archbishop Ioann expressed a desire for reconciliation with the neokruzhniki and for this purpose sent the eminent missionary K. Peretrukhin to different parts of Russia. Kartushin's aspirations, even if they had not achieved the desired goal, stimulated the minds of the Old Belief leaders, aroused lively debate and ample polemic. In each community, it was desirable for the opposing community to acknowledge their guilt and repent of it (Shalkinsky, 1903a, p. 647).

In 1902, K. Peretrukhin came to Gorodishche to reconcile those communities, but he met a fierce rival in the person of the neokruzhniki priest P. Potemkin, so his attempts were fruitless. In 1903, Potemkin during the service informed the believers that the county bishops, led by Ioann (Kartushin), had admitted to «error» and rejected the «Encyclical Epistle» (1862), as containing heresy. In support of his words, he read the hectographed «Confession of Faith» of the neokruzhniki, sent to him by Bishop Michail of Novozybkov, as if having been signed by Archbishop Ioann (Shalkinsky, 1903a, p. 648).

In Gorodishche the okruzhniki, and especially the zealous Malachi Ryndin, could not have allowed the Potemkin fraction (or the neokruzhniki) to be right. Before Christmas, Ryndin, with the Old Believers close to him, went to have a talk at Potemkin's house. After that, he compiled a report to Archbishop Ioann, in which he asked to explain whether it was true that the local priests had repented. In response, Kartushin sent a notice to the priest K. Foteev, drawing attention to the injustice of the neokruzhniki who had tried to slander him, and stressed not to believe their writings (Shalkinsky, 1903b, p. 667-668, 671).

Sergei Shalkinsky in 1903 recalled the emergence of the neokruzhniki in Gorodishche: «The false priest Matvey Grigoryev about 8 years ago fell in disgrace for something with the Moscow false archbishop. Without hesitation, he went to the neokruzhniki false bishop of Novozybkov to get the permission from him, and, arriving in Gorodishche, he began to preach that the okruzhniki were leading the Old Believers to Nikonianism by justifying Nikon's heresies in everything. His sermons resulted in the separation of the local Old Believers» (Shalkinsky, 1903c, p. 766). Although Grigoriev later again switched to the side of the okruzhniki, the neokruzhniki remained. They 
INTERMARUM: history, policy, culture. - Issue 7.

were hostile to the okruzhniki, and did not communicate with them either in prayer or in food and drink (Shalkinsky, 1903c, p. 766).

In 1906, as the result of mutual concessions, a significant event of reconciliation between the okruzhniki and the neokruzhniki took place. The diocese was visited by the reconciled Bishop Michail of Novozybkov, who performed divine services, and read out «forgiveness». But in Gorodishche, many neokruzhniki did not agree to make concessions, and they intended to submit a petition to Iov (Borisov), the neokruzhniki bishop of Moscow who refused to reconcile, to appoint of a new priest. They were of a persistent opinion that Mikhail «had sold his faith» for a lot of money (Report, 1907b, pp. 239-240). It should be noted, previously he was in the region as early as 1900 (Dorodnitsyn, 1901b, p. 270).

Public speeches and polemics with community members, clergy and missionaries were at the heart of the anti-Old Believer mission of the early 20th century. The content of the public talks was widely covered in the diocesan periodicals.

On February 25, 1901, a public talk about the Old Believers took place in the Ekaterinoslav Theological Seminary (ETS), in which the teacher Mikhail Brunbender, the antischismatic missionary, the priest $\mathrm{S}$. Shalkinsky and the ustavshchik of the Old Belief prayer house of Ekaterinoslav Yakov Venediktovich took part. The interest in the conversation was evidenced by the fact that the rector of the seminary, Archimandrite Agapit, the inspector of the seminary P. Okhotsky were also present, and the assembly hall was crowded. In addition to the students of the seminary, there were about 300 visitors (Brunbender, 1901a, pp. 194-195).

During the public talk, the Old Believers did not want to engage in polemics with M. Brunbender and S. Shalkinsky, though they forced them in every way. The invited ustavshchik and okruzhnik Isidor Timofeevich spoke on behalf of the Old Believers (Brunbender, 1901b, p. 228). Yakov Venediktovich raised the question why the Orthodox Church perceived the Old Believers as heretics and accepted them in their fold at the second rank (Brunbender, 1901b, p. 230). Most emotionally, the speakers debated about making the sign of the cross with two (dvoeperstiye) or three (troeperstiye) fingers (Brunbender, 1901c, pp. 274-278, 280). 
IНТЕРМАРУМ: історія, політика, культура. - Вип. 7.

The biased character of the talk is evidenced by M. Brunbender's concluding word: «Their society has never been the true Church of Christ. The true Church of Christ has always been one - our holy GreekRussian Orthodox Church, and only here it is possible to receive salvation» (Brunbender, 1901c, p. 282).

The Orthodox missionaries had to debate not only with ordinary Old Believers, but also with their prominent nachyotchiki. For example, on December 7, 1902, in the Edinoverie church in Orekhovo, S. Shalkinsky and the priest M. Didenko had a public talk about St. Church of Christ and the three-rank hierarchy with the Old Belief missionary K. Peretrukhin, the nachyotchik M. Ryndin and the priest S. Tokarev (Shalkinsky, 1902, p. 207-208).

Interestingly, Peretrukhin was delegated by Archbishop Ioann to clarify the circumstances of Tokarev's case. In 1901, he came to the house of the Orthodox priest Stefan Sobolev in Orekhovo and informed about his desire to join Orthodoxy. Father Stefan invited Tokarev to write a statement, and the latter agreed. Tokarev requested Sobolev for a petition to the senior clergy of the diocese for a post. When Sobolev received a refusal from the consistory, Tokarev accused Father Stefan of slandering. Sobolev placed Tokarev's statement in the village's administration. The Old Believers came to their priest and forewarned him not to appear in the church until he received official permission from Kartushin. The missionary Peretrukhin conducted an investigation and found out that Tokarev was not guilty because during the visit to Father Stefan he had been too drunk, and all his conversations and actions had been performed in a state of insanity (Shalkinsky, 1902, p. 208).

The missionaries engaged pupils of the Ekaterinoslav Theological Seminary in public talks with the Old Believers. On March 31, 1902, there was a public talk with the Austrian faction. It was conducted by the teacher of history and denunciation of schism (raskol) M. Brunbender, with the participation of S. Shalkinsky and I. Tatarinov, a pupil of Form 6. I. Tatarinov delivered a speech «on the illegality of separating schismatics from the Orthodox Church» (Brunbender, 1902a, p. 326-328). To be specific, the pupil expressed the opinion that «the community of the Old Believers has turned to be a surmounted church, 
INTERMARUM: history, policy, culture. - Issue 7.

but the proper church cannot tolerate surmounting» (Brunbender, 1902a, p. 332).

The report provoked a violent reaction from the Old Belief ustavshchik of Ekaterinoslav and the Old Believer Isidor Timofeevich, who, quoting $\mathrm{V}$. Belinsky, appealed to the right of every nation to its originality, as well as to the injustice of «breaking» folk customs (Brunbender, 1902b, pp. 359-363). M. Brunbender, pointed out that the Old Believers were brought under persecution not by the church, but by civil authorities, and the church representatives, driven by the zeal to defend the honor and holiness of the church, only asked the authorities to «limit the willfulness of heretics and schismatics» (Brunbender, 1902c, p. 394).

In 1902, three anti-Old Belief committees functioned in the diocese. The priest-missionary, the chairman of the OlkhovatskGorodishchensk missionary committee S. Shalkinsky dwelt in Gorodishche - the center of the Old Believer diocese, his activities focused on public and private talks (in 1902 - 32 and 17), church sermons and dissemination of anti-Old Believer books and brochures (Ayvazov, 1903b, p. 357, 359-360).

A public talk with the Old Believers of Ekaterinoslav about the reasons for their separation from the Orthodox Greek-Russian Church was held in the Ekaterinoslav Theological Seminary on March 16, 1903. The announcements about it were deliberately pasted around the city and sent to «eminent» Old Believers. Except for M. Brunbender, the main speaker was again the pupil of Form 6 of the seminary V. Krasnitsky. In addition, the event was attended by the diocesan missionary I. Ayvazov and S. Shalkinsky (Brunbender, 1903, p. 292, 294, 304).

In April-May 1904, the notable advocates of the Old Believers Vasily Zelenkov (from Nizhny Novgorod) and Joseph Peretrukhin (from Samara) arrived in Gorodishche and Orekhovo. They conducted public talks with the missionary S. Shalkinsky. The talks touched upon the issues of the eternity of the Church of Christ, the opinions of the Old Believers that the Orthodox Church had been infected with various heresies. Later, S. Shalkinsky accused his opponents of rudeness, impudence and complained: «In order to convey the desired impression 
IНТЕРМАРУМ: історія, політика, культура. - Вип. 7.

on the schismatic mass, they did not skimp on insolence, addressing the missionary a heretic» (Conversations, 1904, p. 495).

V.S. Shalkinsky was the priest of the Edinoverie parish in Gorodishche. In 1904, their house of worship maintained a miserable appearance. It was a small old building without a bell tower, and could accommodated not more than 100 people (Brunbender, 1904, p. 571572).

The question of erecting a stone Edinoverie church was first raised in 1898. Initially, a place for construction was selected in the center of the village, where the old county government building was located. But the village meeting (with the overwhelming majority of the Old Believers) did not agree to allot the designated place. The commission for the construction of the church designated another place in 1900. According to the project, it was planned to construct a church with a capacity of 500 people, and the necessary amount was 21,000 rubles. By January 1, 1904, 14592 rubles were raised for the church construction. It was decided to proceed with the procurement of material. The laying was completed on April 23, 1904, the work quickly advanced and construction was completed in 1905 (Brunbender, 1904, p. 574-576).

The highest decree on strengthening religious tolerance on April 17, 1905, was differently received. The Austrian faction rejoiced, but the bespopovtsy claimed that Antichrist, recognizing the futility to frighten Christians with persecution, sought to seduce them with freedom (Report, 1907a, p. 233).

In 1906, the missionaries noted: «The fighting mood of the Austrian faction, that gripped them after the decree, has not yet subsided: they are hastily trying to implement this law; churches are being constructed and expanded everywhere, brotherhoods and unions are being opened, the magazine «Starobryadets», and «Narodnaya Gazeta» with supplements and the works of their nachyotchiki are being spread among people. Threats against the Orthodox, and sometimes violence, have come to be an ordinary thing» (Report, 1907b, p. 240).

The missionaries conducted public talks in Olkhovatka, Orekhovo, Kamenskoye, Gorodishche, but the Old Believers ignored these events. In Gorodishche, where 12 talks were held, not more than 60 people came (Report, 1907b, p. 240). 
INTERMARUM: history, policy, culture. - Issue 7.

To strengthen his parish, Archbishop Ioann, together with two bishops, visited Gorodishche in 1908 (Afanasyev, Shalkinsky, 1909 p. 28). The bespopovtsy and the beglopopovtsy expressed the desire to unite with the Austrian faction. S. Shalkinsky wrote: «One of the bespopovtsy «spiritual fathers», despite the embarrassment and indignation of his spiritual children, allowed his son to convert into Austrian faction and personally took him for work of penance in the Gorodishche monastery» (Afanasyev, Shalkinsky, 1909 p. 27).

Moreover, in 1908, the Old Believers, addressing the Diocesan Missionary Committee, initiated a dispute in the hall of the Ekaterinoslav Men's Theological School about the eternity of the priesthood or the three-rank hierarchy in the church. P. Pastukhov arranged the meeting on April 6, pointing that mutual conversations remained the easiest way to come to rapprochement and reconciliation. The dispute was attended by the Old Believer nachyotchik Trofim Fedorov (from Nizhny Novgorod), P. Pastukhov from the village Kamenskoye and S. Shalkinsky (Public Conversation, 1908a, p. 448, 451).

The second conversation between T. Fedorov and S. Shalkinsky, again organized at the initiative of the Old Believers, took place on May 14. The meeting was held in the hall of the factory in Kamenskoye, and the topic was whether the Orthodox Church had preserved the union of faith with the Ancient Universal Church (Public Conversation, 1908b, p. 607).

In 1908, the diocesan magazine published an article by Nikolai Kochanov, in which the author pointed out the need to study the foundations of the Old Belief, to organize the Department of history and the exposure of the Old Belief schism in the seminaries. For N. Kochanov and for many other Orthodox, the Old Believers were «the gloating enemies of Orthodoxy» (Kochanov, 1908, p. 525).

One cannot ignore Nikolai Kochanov's interpretation of the Old Belief, because obviously, it should have influenced the entire Orthodox clergy of the diocese: «Schism, as a doctrine, represents a letterbelieving direction in religious life. It is distinguished by special pettiness, attachment to the letter of the rite. The rite is promoted here to the rank of a dogma» (Kochanov, 1908, p. 524). 
IНТЕРМАРУМ: історія, політика, культура. - Вип. 7.

S. Shalkinsky was a notable person in missionary. In 1908, he took part in the Kiev Missionary Congress, where during the preliminary commission he was elected the secretary of the Edinoverie department and during the congress he was elected the secretary of the anti-Raskol department. But in the same year, S. Shalkinsky became ill. After 15 years of missionary work, on account of illness, he was forced to abandon his activities (Afanasyev, Shalkinsky, 1909 p. 29).

His father, the priest Pavel, was approved as an anti-Raskol missionary in 1909. He focused his activities mainly on sermons against the Old Believers in the Edinoverie Holy Spirit Church in Gorodishche (From life, 1909a, p. 167). It should be noted, that P. Shalkinsky conducted almost all the sermons exclusively against the Austrian faction, in one of which, on May 5, he identified them with the blind (From life, 1909b, p. 588-589).

The September public talks of P. Shalkinsky with the Old Believers in Orekhovo were attended by respected nachyotchiki Ivan Lukin (on behalf of the Austrian faction) and Lev Pichugin (on behalf of the Bespopovtsy), who had two talks between themselves about the eternity of the church and the priesthood. After the talks, the local Edinoverie priest Naum Sychev converted three Old Believers to the Edinoverie. The missionary and Lukin also had talks in the village Olkhovatka (State of schism, 1910, p. 22-24).

Since 1909, the Old Believers has become interested in the religious teachings of Protestants, namely in the villages of Olkhovatka and Gorodishche. In the latter, 9 Old Believers adopted Baptism (State of schism, 1910 p. 21). Officially, in 1910 there were 20 Baptists and Adventists the former Old Believers in Gorodishche (Afanasyev, 1911, p. 210). As a result, the missionary P. Shalkinsky had to enter into a dispute with Protestants to preserve his Ediniverie parish (Afanasyev, 1912, p. 461).

The former missionary priest S. Shalkinsky was also worried about the situation in Gorodishche. Speaking at the diocesan missionary congress on June 11, 1913, he even admitted: «I have spread sectarianism in Gorodishche» (Pokrovsky, 1914, p. 853).

Despite the activity of the Orthodox mission, the Old Believers were skeptical of the missionaries' arguments. A vivid example is the statistics of adopting Orthodoxy. In 1900, 16 Old Believers converted to 
INTERMARUM: history, policy, culture. - Issue 7.

Orthodoxy, in $1904-5$, in $1905-20$, in $1906-5$, and in $1911-2$ (Dorodnitsyn, 1901b, p. 272; Rusanov, 1905, p. 339; Report, 1907a, p. 236; Report, 1907b, p. 241; Afanasyev, 1912, p. 461).

In 1912, the psalmist from the Saratov diocese Alexander Ermakov, was sent to P. Shalkinsky as an assistant. After that, although the statistical indicators remained high, more than 100 public talks were held, but the attitudes were the same. The missionary concentrated his attention not on the whole diocese, but exclusively on Gorodishche, exactly like in 1910, when 98 public talks were organized there (Afanasyev, 1911, p. 210; State of the Old Believers, 1913, p. 257).

After a serious illness in 1914, the missionary priest S. Shalkinsky, actually, an unofficial assistant to his father, the anti-Old Belief missionary and the priest Pavel, died (Pokrovsky, 1914, p. 853). It was an irreplaceable loss for the Orthodox mission, that led to a sharp decrease in the effectiveness of activities among the Old Believers.

Conclusions. At the beginning of the 20th century, about 10000 Old Believers lived in the Ekaterinoslav Diocese. The okruzhniki constituted the overwhelming majority, while the neokruzhniki, the bespopovtsy, and the beglopopovtsy represented smaller groups. The conflict was acute in the clergy, between the okruzhniki and the neokruzhniki. The confrontation gradually began declining after the act of reconciliation in 1906, although some believers, in particular in Gorodishche, categorically did not accept it. The «fight» against the Old Believers was of primary importance for the Orthodox missionary. The residence of the anti-Raskol missionary was Gorodishche, where he served as a priest of the Edinoverie parish. The missionaries were opposed by the Old Believer authorities, such as the nachyotchiki C. Peretrukhin, V. Zelenkov, L. Pichugin, and others. Since the end of the 19th century, the missionary activity among the Old Believers was carried out by S. Shalkinsky, a dedicated priest. However, the success of the mission was insignificant, due to the steadfastness of the Old Believers in their religious beliefs and the particular attention of the missionaries to the spread of new religious movements and sects in Christianity. 
IНТЕРМАРУМ: історія, політика, культура. - Вип. 7.

\section{BIBLIOGRAPHY}

Ayvazov, I. (1903a). State of schism and sectarianism and the activities of the Orthodox mission in the Ekaterinoslav Diocese in 1902. Ekaterinoslav Diocesan Bulletin, 13 (unofficial part), 327-333. [In Russian].

Ayvazov, I. (1903b). State of schism and sectarianism and the activities of the Orthodox mission in the Ekaterinoslav Diocese in 1902. Ekaterinoslav Diocesan Bulletin, 14 (unofficial part), 354-362. [In Russian].

Ayvazov, I. (1904). State of sectarianism and schism and the activities of the Orthodox mission in the Ekaterinoslav Diocese in 1903. Ekaterinoslav Diocesan Bulletin, 8 (unofficial part), 242-254. [In Russian].

Afanasyev, A. (1911). State of sectarianism and schism and the activities of the Orthodox mission in the Ekaterinoslav Diocese in 1910. Ekaterinoslav Diocesan Bulletin, 7 (unofficial part), 204-212. [In Russian].

Afanasyev, A. (1912). State of sectarianism and schism and the activities of the Orthodox mission in the Ekaterinoslav Diocese in 1911. Ekaterinoslav Diocesan Bulletin, 8 (unofficial part), 417-462. [In Russian].

Afanasyev, A., Shalkinsky, S. (1909). State of sectarianism and schism in the Ekaterinoslav Diocese in 1908. Ekaterinoslav Diocesan Bulletin, 10 (unofficial part, addition), 13-29. [In Russian].

Brunbender, M. (1901a). Public conversation with Old Believers in the assembly hall of the Ekaterinoslav Theological Seminary on February 25, 1901. Ekaterinoslav Diocesan Bulletin, 8 (unofficial part), 194-201. [In Russian].

Brunbender, M. (1901b). Public conversation with Old Believers in the assembly hall of the Ekaterinoslav Theological Seminary on February 25, 1901. Ekaterinoslav Diocesan Bulletin, 9 (unofficial part), 227-231. [In Russian].

Brunbender, M. (1901c). Public conversation with Old Believers in the assembly hall of the Ekaterinoslav Theological Seminary on February 25, 1901. Ekaterinoslav Diocesan Bulletin, 10-11 (unofficial part), 273-282. [In Russian]. 
INTERMARUM: history, policy, culture. - Issue 7.

Brunbender, M. (1902a). Conversation with the Old Believers receiving the Austrian priesthood in the hall of the Ekaterinoslav Theological Seminary. Ekaterinoslav Diocesan Bulletin, 14 (unofficial part), 326-332. [In Russian].

Brunbender, M. (1902b). Conversation with the Old Believers receiving the Austrian priesthood in the hall of the Ekaterinoslav Theological Seminary. Ekaterinoslav Diocesan Bulletin, 15 (unofficial part), 358-365. [In Russian].

Brunbender, M. (1902c). Conversation with the Old Believers receiving the Austrian priesthood in the hall of the Ekaterinoslav Theological Seminary. Ekaterinoslav Diocesan Bulletin, 16 (unofficial part), 388-395. [In Russian].

Brunbender, M. (1903). Conversation with Old Believers in a Theological Seminary. Ekaterinoslav Diocesan Bulletin, 11-12 (unofficial part), 292-304. [In Russian].

Brunbender, M. (1904). The Church of Common Faith in the village Gorodishche of Slavyanoserbsky district. Ekaterinoslav Diocesan Bulletin, 18 (unofficial part), 570-576. [In Russian].

Dorodnitsyn, A. (1901a). Report on the state of sectarianism in the Ekaterinoslav Diocese for 1900. Ekaterinoslav Diocesan Bulletin, 9 (unofficial part), 221-227. [In Russian].

Dorodnitsyn, A. (1901b). Report on the state of sectarianism in the Ekaterinoslav Diocese for 1900. Ekaterinoslav Diocesan Bulletin, 10-11 (unofficial part), 268-273. [In Russian].

From life (1909a). From life of the mission of the Ekaterinoslav Diocese. Ekaterinoslav Diocesan Bulletin, 6 (unofficial part), 162-167. [In Russian].

From life (1909b). From life of the mission of the Ekaterinoslav Diocese. Ekaterinoslav Diocesan Bulletin, 22 (unofficial part), 586-589. [n Russian].

Klepalova, H., Lukovenko, I. (2001). From history of Old Believers in Donbass. History of Ukraine. Lesser-known names, events, facts, 18, 286-289. [In Ukrainian].

Kochanov, N. (1908). The need to study schism-Old Believers by the students of the seminary, as future pastors of the church. Ekaterinoslav Diocesan Bulletin, 16 (unofficial part), 522-527. [In Russian]. 
IНТЕРМАРУМ: історія, політика, культура. - Вип. 7.

Miroshnychenko, O. (2019). Ukrainian Old Believers and Russian Power (late 18th - early 20th centuries). Problems of Political History of Ukraine, 14, 16-23. doi: 10.33287/1192 [In Ukrainian].

Nestertsova, S., Mayorova, Ye. (2012). Old Believers in the Donbass in the 19th and early 20th centuries. New pages of Donbas history, 21, 158-169. [In Russian].

Report (1907a). Report on the state of schism and sectarianism and the activity of the Orthodox mission in the Ekaterinoslav Diocese for 1905-6. Ekaterinoslav Diocesan Bulletin, 10 (unofficial part), 226-236. [In Russian].

Report (1907b). Report on the state of schism and sectarianism in the Ekaterinoslav Diocese for 1906. Ekaterinoslav Diocesan Bulletin, 11 (unofficial part), 239-245. [In Russian].

Pokrovsky, I. (1914). Memo. Ekaterinoslav Diocesan Bulletin, 32 (unofficial part), 853-855. [In Russian].

Public conversation (1908a). Public conversation with the Old Believers. Ekaterinoslav Diocesan Bulletin, 13 (unofficial part), 448452. [In Russian].

Public conversation (1908b). Public conversation with Old Believers in the village Kamenskoye. Ekaterinoslav Diocesan Bulletin, 20 (unofficial part), 607-615. [In Russian].

Ruban, M., Tatarynov, S. (2017). Old Believers of Donbass from the 18th to the beginning of 20th centuries: historical-confessional aspect. Volynskyi Blahovisnyk, 5, 135-143. [In Ukrainian].

Rusanov, M. (1905). State of sectarianism and schism in the Ekaterinoslav Diocese in 1904. Ekaterinoslav Diocesan Bulletin, 11-12 (unofficial part), 332-340. [In Russian].

Conversations (1904). Conversations in the village Gorodische of the Slavyanoserbsky district with schismatic dogmatists. Ekaterinoslav Diocesan Bulletin, 16 (unofficial part), 495-497. [In Russian].

State of schism (1910). State of schism in the Ekaterinoslav Diocese in 1909. Ekaterinoslav Diocesan Bulletin, 8 (unofficial part, addition), 21-24. [In Russian].

State of the Old Believers (1913). State of the Old Believers in the Ekaterinoslav Diocese in 1912. Ekaterinoslav Diocesan Bulletin, 10 (unofficial part), 256-257. [In Russian]. 
INTERMARUM: history, policy, culture. - Issue 7.

Sychevsky, A. (2013a). Formation and spread of Common Faith in Volynian diocese (1904-1922). Vestnik of Orenburg State Pedagogical University. Electronic Scientific Journal, 4, S. 91-104.

http://vestospu.ru/archive/2013/articles/15_4_2013.pdf

[in Russian].

Sychevsky, A. (2013b). Cathedral named after the holy martyr Ignatiy Bogonosec in Zhytomyr: to history of the temple structure (1856-1927). Ukraine: Cultural Heritage: Proceedings of the 5th AllUkrainian Scientific Conference «Weingort Readings», 153-164. Poltava. [In Russian].

Sychevsky, A. (2012). Activity of orthodox mission among Old Believers of the Volyn province in the years 1904-1914 (on materials of the «Volyn eparchial journal»). Gurzhiev Historical Readings, (5), 172175. [In Ukrainian].

Shalkinsky, S. (1902). Chronicle of the diocesan mission. Ekaterinoslav Diocesan Bulletin, 9 (unofficial part), 207-210. [In Russian].

Shalkinsky, S. (1903a). In the world of schism (to the question of the desire of the «okruzhniki» to come to reconcile with the «protivookruzhniki»). Ekaterinoslav Diocesan Bulletin, 24 (unofficial part), 647-650. [In Russian].

Shalkinsky, S. (1903b). In the world of schism (to the question of the desire of the «okruzhniki» to come to reconcile with the «protivookruzhniki»). Ekaterinoslav Diocesan Bulletin, 25 (unofficial part), 667-671. [In Russian].

Shalkinsky, S. (1903c). In the world of schism (to the question of the desire of the «okruzhniki» to come to reconcile with the «protivookruzhniki»). Ekaterinoslav Diocesan Bulletin, 28 (unofficial part), 762-768. [In Russian].

State of the Old Believers in the Ekaterinoslav Diocese in 1912. (1913). Ekaterinoslav Diocesan Bulletin, 10 (otdel neofitsialnyy), 256257. [In Russian].

Sychevsky, A. (2013a). Formation and spread of Common Faith in Volynian diocese (1904-1922)]. Bulletin of Orenburg State University, (4), 91-104. http://vestospu.ru/archive/2013/articles/15_4_2013.pdf [in Russian]. 
ІНТЕРМАРУМ: історія, політика, культура. - Вип. 7.

Sychevsky, A. (2013b). Cathedral named after the holy martyr Ignatiy Bogonosec in Zhytomyr: to history of the temple structure (1856-1927). Ukraine: Cultural Heritage. Proceedings of the AllUkrainian Conference (V) «Wayhort's reading» (153-164). Poltava. [in Russian].

Shalkinsky, S. (1902). Chronicle of the diocesan mission. Ekaterinoslav Diocesan Bulletin, (9), 207-210. [in Russian].

Shalkinsky, S. (1903a). In the world of schism (to the question of the desire of the «okruzhniki» to come to reconcile with the «protivookruzhniki». Ekaterinoslav Diocesan Bulletin, (24), 647-650. [in Russian].

Shalkinsky, S. (1903b). In the world of schism (to the question of the desire of the «okruzhniki» to come to reconcile with the «protivookruzhniki». Ekaterinoslav Diocesan Bulletin, (25), 667-671. [in Russian].

Shalkinsky, S. (1903c). In the world of schism (to the question of the desire of the «okruzhniki» to come to reconcile with the «protivookruzhniki»). Ekaterinoslav Diocesan Bulletin, (28), 762-768. [In Russian].

\section{СИчевськИй Антон. СТАРООБРЯДЦІ КАТЕРИНОСЛАВСЬКОЇ СПАРХІЇ ТА ДІЯЛЬНІСТЬ ПРАВОСЛАВНӦ̈ МІСІЇ НА ПОЧАТКУ ХХ СТОЛІТТЯ}

\section{Анотація}

Мета дослідження - висвітлити релігійне життя старообрядиів Катеринославської єпархї на початку XX cm. та проаналізувати специфіку діяльності православної місї в їх середовищі. Методологія дослідження трунтується на принщипах історизму, системності, авторській об'єктивності, а також на використанні загальнонаукових (аналіз, синтез, конкретизації, узагальнення) $i$ спеціально-історичних (проблемно-хронологічного, історико-генетичного, історико-типологічного) методів. Використання проблемно-хронологічного методу дозволило проаналізувати релігійне життя старообрядницьких громад Катеринославської єпархї, виявити особливості віросповідної політики правлячої православної церкви у відношенні до старообрядиів в певних хронологічних рамках. Історико- 
INTERMARUM: history, policy, culture. - Issue 7.

генетичний метод застосовувався при аналізі трансформацій старообрядництва Катеринославської спархії та конфесійної політики православної иеркви. Історико-типологічний метод був важливий при вивченні внутрішнього розподілу та конфліктності в старообряднищтві Катеринославської спархї, а також використовувався при розгляді форм реалізацій конфесійної політики. Наукова новизна полягає в тому, щзо вперше на маловідомих матеріалах спархіальної періодики початку XX $\mathrm{cm}$. комплексно розкрито внутрішній розподіл старообрядництва Катеринославської єпархї̈, протікання конфлікту між окружниками $і$ неокружниками, розглянуто форми та методи місіонерської діяльності панівної православної церкви. Висновки. Встановлено, щуо на початку XX ст. в межах Катеринославської єпархї̈ проживало близько 10000 старообрядиів, з яких переважна частина належала до попівиів-окружників, а значно меншими були громади неокружників, безпопівців та біглопопівців. Найвпливовішим центром старообрядиів-окружників в Катеринославській спархї було с. Городище, де вони складали більшість населення, а для безпопівців - с. Орєхово, для неокружников - с. Камєнскоє. Вагомого значення набув $і$ духовний иентр старообрядиів Донбаського регіону - Преображенський скит. В основі внутрішніх конфліктів у громадах були стосунки зі священиками, які свойми вчинками викликали обурення у пастви. Особливого розголосу набула справа С. Токарева - священика старообрядиів с. Орєхово, який з меркантильних поглядів вирішив перейти в православ'я. Досить гострим був конфлікт в поповщчині, між окружниками та неокружниками, який поступово йшов на спад після акту примирення в 1906 р., хоча частина вірян, зокрема в с. Городище, його категорично не сприймала. Варто відмітити, щзо на шляху до примирення партія окружників у 1902 р. зіткнулася $з$ інспірованою провокацією відносно їхнього Московського архієпископа Іоанна (Картушина), яку вдалося викрити саме завдяки увазі та непоступливості представника громади с. Городище, - М. Риндіна. «Боротьба» із старообрядництвом була одним з пріоритетних напрямів роботи інституту православного місіонерства в спархї. Опонентами єпархіальних місіонерів ставали як представники місиевого 
IНТЕРМАРУМ: історія, політика, культура. - Вип. 7.

духовенства та рядові старообрядиі, так і визнані авторитети старообрядницькі начотчики $K$. Перетрухін, B. Зеленков, Л. Пічугін та ін. Незважаючи на високий рівень організації та роботи інституту місіонерства, безпосередні успіхи місї були обмежені.

Ключові слова: старообрядництво, місіонерство, окружники, неокружники, безпопівці, єдиновірство, «Окружне послання».

\section{Syczewski Anton. STAROOBRZEDDOWCY W \\ JEKATER YNOSEAWSKIEJ DIECEZJI I DZIALALNOŚĆ MISJI PRAWOSEAWNEJ NA POCZAZTKU XX WIEKU}

\section{Streszczenie}

Celem badania jest odkrycie życia religijnego staroobrzędowców $w$ diecezji Jekaterynosławskiej na poczatku XX wieku i przeanalizowanie specyfiki działań misji prawosławnej $w$ ich środowisku. Metodologia opiera się na zasadach historyzmu, systematyczności, naukowości, autorskiego obiektywizmu, a także na zastosowaniu ogólnonaukowych metod (analiza, synteza, uogólnienie) i specjalno-historycznych metod (historyczno-typologicznych, historyczno-systemowych). Oryginalność naukowa polega na tym, że po raz pierwszy wszechstronnie ujawniono wewnętrzna dystrybucję staroobrzędowców $z$ diecezji Jekaterynosławskiej, odzwierciedlono przebieg konfliktu między "okrużnikami" $i$ "nieokrużnikami", formy $i$ metody działalności misyjnej. Wnioski. Na poczatku XX wieku w diecezji byto 10000 staroobrzędowców, z których przeważająca większość należała do popowców-okrużników, a mniejsze byly wspólnoty "nieokrużników”, "bezpopowców" $i$ "biegłopopowców". Podstawa wewnętrznych konfliktów we wspólnotach byly stosunki z kapłanami, którzy swoimi czynami wywołali oburzenie wśród parafian. Sprawa księdza S. Tokariewa zyskała szczególny rozgtos. Konflikt byt ostry $w$ duchowieństwie, między "okrużnikami” $i$ "nieokrużnikami”, który stopniowo zacząt iść na spadek po ukazie tolerancyjnym w 1906 r. Po drodze do zgody partia "okrużników" spotkała się z natchniona prowokacja przeciwko arcybiskupowi Janowi. "Walka" ze staroobrzędowcami była jednym $z$ priorytetowych zadań instytutu prawosławnego misjonarstwa. Oponentami diecezjalnych misjonarzy zostali zarówno przedstawiciele duchowieństwa $i$ zwyczajni 
INTERMARUM: history, policy, culture. - Issue 7.

staroobrzędowcy, tak $i$ autorytety - staroobrzędowi dogmatycy $K$. Peretruchin, W. Zelenkow, L. Piczugin i inni. Pomimo wysokiego poziomu organizacji $i$ dzałania instytutu misjonarstwa, bezpośredni sukces misji byt ograniczony.

Stowa kluczowe: staroobrzędowcy, misjonarstwo, okrużniki, nieokrużniki, bezpopowce, jednowierstwo, „przestanie okręgowe”.

The article was received 10.18.2019 Article recommended for publishing 11.29.2019 